Research Article

\title{
Financial Performance of Janapriya Multiple Campus Pokhara
}

\author{
Hari Bahadur Bhand ari \\ Adjunct Faculty, Janapriya Multiple Campus
}

Article History

Received 26 May, 2018

Revised 19 June 2018

Accepted 30 November 2018

\section{Abstract}

Financial performance analys is is based on financial statement. Financial statement is the final product of accounting process. Fundamentally, financial performance analys is refers to financial statement analys is to identify financial strength and weaknesses by establishing appropriate relationship among the figures of income statement and balance sheet. The main objective behind this study was to assess the financial performance of Janapriya Multiple Campus (JMC). Beside this, it also aimed to compare the financial performance and analyze the financial changes over a period of five years along with examining the cost recovery rate of JMC. This research was done with the help of secondary data entirely gathered from the annual report and official documents of the campus. The financial performance measured by using various financial/accounting and statistical tools such as common size financial statement, horizontal trend percent analysis, profitability ratios, mean and standard deviation. Based on the analysis, internal sources of fund including reserve and surplus, long term fund and campus development fund contribute more than $65 \%$ of the total liabilities/total assets. The highest percentage of permanent capital and fixed assets denote that the durable assets and fixed deposit amount were covered by the internal sources of fund. Findings have been arrived that the campus has got enough current assets to meet its current liabilities. The income statement shows total revenues increased every year at good rate and profit also increased every year except the years of 2070/71 and 071/72. In average, all profitability ratios are positive. Moreover, the analys is of collected data showed that there is no high fluctuation in the calculated profitability ratios and cost recovery rate. There exist positive relationship between revenue and expenses but the relationship is insignificant. Revenue explains 52.3 percent variation of variation in expenses. However, the institution is financially viable and there is a strong possibility to make money in long run.

Key Words: Assets, expenses, financial performance, financial statement, profitability ratio, revenue

(C) The author. Published by JRCC, Janapriya Multiple Campus

ISSN 2362-1516

\section{Introduction}

Basic and minimum level objective of any organization is to survive at any cost. And then, they can seek for long term existence in this tough competition age. Long term existence is possible only when the organizations can earn sufficient operating profit by using their scarce resources. Profit is not god gifted. Nor it happens by chance. It has to be managed by each and every organization. 
Ultimate goal of profitability can be achieved by efficient use of resources. It is related with maximization of wealth and can be attained through financial performance analysis. Financial performance is a subjective measure of how well an organization uses its resources to generate revenues. This term is also used as a general measure of a firm's overall financial health over a given period of time, and can be used to compare with similar organization. Financial performance refers to the act of performing financial activity. Financial performance analysis is the process of determining the operating and financial characteristics of a firm from accounting and financial statements. The goal of such analysis is to determine the efficiency and performance of firm's management as reflected in the financial records and reports (Bhunia, Mukhuti \& Roy, 2011).

Financial performance analys is is necessary for the proper management of profit which is based on financial statement of a certain accounting period. Financial statement comprises income statement, statement of retained earnings, balance sheet and cash flow statement. Income statement is a profit and loss account that summarizes operation result of an organization for a given time period. It shows whether a concern making or losing money (Pillai \& Bagavathi, 1998). Statement of retained earning shows profit retained after appropriation. The retained profit is the amount that can be reinvested in an organization. Balance sheet is a financial statement that shows financial position of a concern for a particular point of time. It is a status statement as it shows the financial status of any organization on a particular date (Gupta \& Radhaswamy, 1996). Cash flow statement provides information about inflow and outflow of cash of a firm in an accounting period. It is a part of financial statement which explains the changes in cash position from one balance sheet date to another balance sheet date (Dangol \& Dangol, 2010).

Financial statements are the most important sources of information to all the users of accounting information like lenders, suppliers, government agencies, financial analyst, employees, organization's management etc. Employees can use them to demand for additional salary and benefits. Lenders use them to make lending decision. Government may use the same to formulate tax policies. The statement acts as a basis for management to perform managerial functions like planning, promotion, decision making, research and development etc.(Koirala et al., 2013).

Financial statement analysis is the process of identifying financial strengths and weaknesses of the firm by establishing proper relationship among the figures of financial statement (Bajracharya et al., 2014). Financial performance analys is is prepared mainly for decision-making purposes. The information given in the financial statements is of immense use in making decisions through analysis and interpretation of financial statements. Comparative Financial Statement analysis provides information to assess the direction of change in the business. Financial statements are presented on a particular date for a particular period. The balance sheet indicates the financial position at the end of an accounting period and income statement shows the operating and nonoperating results for a period. But financial managers and top management are also interested in knowing whether the business is moving in a favorable or an unfavorable direction. For this purpose, figures of current year have to be compared with those of the previous years. In analyzing 
this way, comparative financial statements are prepared (Ravichandran \& Subramanian,2016). Successful investing has no secret formula. A good strategy and a basic understanding of the rules of the game are required to do well in the long run. Since financial statements are basic tools of fundamental analysis, it is important to be able to read and analyze them. Financial statements provide the means to measure the performance of the company and its management (Bajkowski,1999).

Financial statement analysis is the collective name for the tools and techniques that are intended to provide relevant information to decision makers. This analysis enables investors to evaluate past performance and financial position, and to predict future performance. Information about past performance is useful in judging future performance. Trends of past income, earnings, surplus, cash flow, return on assets etc. provide basis for evaluating the efficiency of an organization and helps in assessing its prospect (Narayanaswamy, 2003). Financial analysis is the process of assessing the financial position of a company by analyzing its stability, viability and profitability. One of the primary objectives of financial analysis is to recognize changes in financial trends, to help measure the progress made by an enterprise and identify a relationship to draw a logical conclusion on the performance of the company. Profitability and financial performance could be defined as a measurement of the results of a firm's polices and operations in monetary terms (Sultan, 2014).

The main problem in any organization is making correct estimates for the future which cannot be done unless data representing changes over a period are systematically and scientifically analyzed. Financial analysis is a powerful mechanism which helps to ascertain the strength and weakness in the operation and financial position of an enterprise. Financial analysis is the process of identifying the financial health of the firm by properly establishing relationship between the items of the balance sheet and the profit and loss account. To be more specific to the problem, the study tries to answer the research questions, what is the order of magnitude of changes in income, expenses, assets and liabilities? What are the major changes in the financial statement items for successive study period? What is the position of cost recovery rate? Thus, the main objective of this paper is to assess the financial performance of JMC. In addition to this, it also aims to compare the financial performance and to analyze the financial changes over a period of five years and to examine the cost recovery rate of JMC. The finding of this paper has to be cautiously and carefully used because the analysis is based only on the last five years.

Prior to this, studies were limited to manufacturing company, trading stores, hospitals and constituent colleges. There is not any study that has been done on financial performance of public campus like JMC. Therefore, the study will certainly be much worthy as it will fulfill the lack. This paper, obviously, will help to formulate plans and policies regarding revenue maximization and cost minimization of JMC. Providing a base for the further studies to researchers on related topic will be another additional merit of the study. 


\section{Conceptual Frame work}

Income statement and balance sheet are very important reports of any organization in assessing the overall financial position as income statement captures the company's operating performance and balance sheet shows its net worth. Financial performance could be assessed using the following key measures which are important to assess the current financial position and performance. These are descriptive and analytical measures of financial position and performance. The former includes current assets, current liabilities, total assets, total revenues, total expenses and net surplus. And analytical measures of financial position and performance could include profitability measures. Thus, researcher would like to study and investigate the financial statements of JMC, its profitability and performance. The income statement and balance sheet are the outcome of accounting process of a certain period of time that provides valuable information to stakeholders. Every firm is mostly concerned with its profitability and performance. Therefore, the general purpose of a financial statement is aimed to meet the need of a wide range of users. Most of the organizations have a main objective to maximize their profits. Traditionally, the firm performance is evaluated based on profits, reflected in the income statement. Financial statements analysis measures performance and profitability of any firm. Horizontal analys is, vertical analys is, cost recovery rate, return on assets, return on fixed assets and return on net worth are used to measure the financial performance.

The absolute accounting figures reported in the financial statements does not provide any fruitful meaning until and unless the figures are compared to each other. The study is concerned on financial analysis to evaluate the financial performance and profitability of the campus. The future plans and policies of JMC should be laid down in view of the firm's financial strength and weakness by properly establishing relationship between the items of balance sheet and income statement. It is only rearrangement of data given in financial statements, and analysis and discussions are based on the available data. Inter campus comparison is not possible because the study covers only one campus.

\section{Data and Methods}

JMC, a QAA certified public campus affiliated to Tribhuvan University and National Education Board, Nepal, was established in 1991A.D with the active involvement of local community including social workers, teachers, educationist and social organizations having 14 teaching staff, 4 
non teaching staff and 124 students in proficiency certificate of Management and Humanities faculties situated in a centre of clean and beautiful city of Nepal, Pokhara. JMC has been offering plus two level in management, science, education and humanities, BBS, BBA, BA, B. Ed, B.Sc. Environment, B.Sc. Microbiology, BMTM of Bachelor level and MBS of Master level along with 126 teaching staff, 42 non teaching staff and 4042 students. There is no any study about the financial soundness of this campus. Easy accessibility of data, less time consuming and cost effectiveness are the major responsible factors behind the causes of selecting the study area. This paper totally depends upon the secondary sources of quantitative audited data annually published by JMC ranging from fiscal years $069 / 70$ to $073 / 74$. The reliability of secondary data has not been examined but the ethical approval has been taken from JMC to conduct research work based on the audited published secondary data. Descriptive and analytical research design was used to achieve the research objectives. The collected data have been presented in a tabular form. Tables related with common size comparative balance sheet, common size comparative income statement, cost recovery rate and return in relation to total assets, net worth and total revenue are presented separately. The data have been analyzed with the help of financial and statistical tools like percentages, proportions, ratios, mean and standard deviation. Collected data were analyzed through the use of statistical packages for social sciences (version 22) software.

Expenses are made by any organization to increase revenue and the expenses are based on income level. Hence, a estimating linear equation of the expenses and income has been used in the form of $\mathrm{Y}=\mathrm{a}+\mathrm{bx}$ where, $\mathrm{y}$ stands for expenses, a stands for intercept, $\mathrm{b}$ stands for slope of the line and $\mathrm{x}$ stands for income. A statistical hypothesis for the dependent and independent variables has been tested as well. For this purpose, the null hypothesis $\mathrm{H}_{1}$, there is no significant relationship between expenses and revenue/income is formulated and tested at 5\% level of significance. Simple correlation technique has been used to measure degree of relationship between the two variables.

\section{Result and Discussion}

Common size or vertical analysis is a method of evaluating financial information by expressing each item of a financial statement as a percentage of a base amount for the same time period. Common size balance sheet displays both the numeric value and relative percentage for total assets/total liabilities. Table 1 shows that the internal fund including reserve and surplus, long term fund and campus development fund cover major portion of total liabilities of JMC. The amount of outstanding expenses in relation to the total liabilities is in second position. Total assets of JMC include fixed assets, fixed deposit, advance, bank balance and closing stock. There is high 
investment in the fixed as sets by the campus which can be taken as a symbol of bright future of earning.

\section{Table 1}

\section{Common Size Comparative Balance Sheet}

\begin{tabular}{|c|c|c|c|c|c|c|c|c|c|c|}
\hline \multirow[t]{2}{*}{ Particulars } & \multicolumn{2}{|c|}{$2069 / 70$} & \multicolumn{2}{|c|}{$2070 / 71$} & \multicolumn{2}{|c|}{$2071 / 72$} & \multicolumn{2}{|c|}{$2072 / 73$} & \multicolumn{2}{|c|}{$2073 / 74$} \\
\hline & Rs. & $\%$ & Rs. & $\%$ & Rs & $\%$ & Rs. & $\%$ & Rs. & $\%$ \\
\hline Capital and & & & & & & & & & & \\
\hline liabilities & & & & & & & & & & \\
\hline $\begin{array}{l}\text { Reserve and } \\
\text { surplus }\end{array}$ & 53738368 & 65.1 & $5,08,93,982$ & 52.0 & $3,71,25,297$ & 42.3 & $4,37,18,307$ & 40.6 & $6.57,36,738$ & 47.7 \\
\hline $\begin{array}{l}\text { Long term } \\
\text { fund }\end{array}$ & $1,26,23,282$ & 15.3 & $1,97,31,272$ & 20.2 & $2,08,71,817$ & 23.8 & $2,54,74,030$ & 23.7 & $2,73,98,432$ & 19.8 \\
\hline $\begin{array}{l}\text { Campus } \\
\text { development } \\
\text { fund }\end{array}$ & $13,43,991$ & 1.6 & $13,43,991$ & 1.4 & $13,43,991$ & 1.5 & $13,43,991$ & 1.3 & $13,43,991$ & 0.9 \\
\hline $\begin{array}{l}\text { Account } \\
\text { payables } \\
\text { Outstanding }\end{array}$ & $2,53,555$ & 0.3 & 48,555 & 0.1 & $1,16,232$ & 0.1 & $1,16,232$ & 0.1 & $1,16,232$ & 0.1 \\
\hline expenses & $1,45,84,882$ & 17.7 & $2,58,44,296$ & 26.4 & $2,84,20,088$ & 32.3 & $3,69,84,577$ & 34.4 & $4,32,81,001$ & 31.4 \\
\hline Total & $8,25,44,078$ & 100 & $9,78,62,096$ & 100 & $8,78,77,425$ & 100 & $1076,37,137$ & 100 & $1378,76,394$ & 100 \\
\hline Assets & & & & & & & & & & \\
\hline $\begin{array}{l}\text { Fixed as sets } \\
\text { Fixed }\end{array}$ & $4,55,28,884$ & 55.16 & $4,79,29,175$ & 48.9 & $4,50,69,743$ & 51.3 & $4,50,18,244$ & 41.8 & $679,30,853$ & 49.3 \\
\hline deposit & $59,63,982$ & 7.23 & $1,17,52,982$ & 12.1 & $1,05,64,786$ & 12.2 & $1,48,66,007$ & 13.8 & $1,48,66,007$ & 10.8 \\
\hline Bank & & & & & & & & & & \\
\hline $\begin{array}{l}\text { balance } \\
\text { Advance }\end{array}$ & $\begin{array}{r}2,39,84,989 \\
65,26866\end{array}$ & $\begin{array}{c}29.1 \\
79\end{array}$ & $\begin{array}{l}1,75,48,568 \\
201,24,000\end{array}$ & $\begin{array}{l}17.9 \\
206\end{array}$ & $\begin{array}{r}79,15,820 \\
237,24,000\end{array}$ & 9.1 & $1,57,20,535$ & 14.6 & $1,81,26,707$ & 13.2 \\
\hline Closing & & & & & & 27.0 & $3,14,49,539$ & 29.2 & $3,64,74,739$ & 26.5 \\
\hline stock & $5,39,357$ & 0.7 & $5,07,371$ & 0.5 & $6,03,076$ & 0.7 & $5,82,812$ & 0.5 & $4,77,907$ & 0.4 \\
\hline Total & $82,54,4078$ & 100 & $9,78,62,096$ & 100 & $8,78,77,425$ & 100 & $1076,37,137$ & 100 & $1378,76,394$ & 100 \\
\hline
\end{tabular}

Source: Annual reports of JMC (069/70 - 073/74)

In table 2, common size income statement shows all income and expenditure in figures and percentage of expenses on the basis of total revenue. It clears that most of the revenue is consumed by salary and TADA. All other expenses are nominal and less than 10 percent except office operating expenses of 070/71 in comparison with total revenue. The table depicts that the revenue cannot cover entire expenses during 070/71 and 071/72 due to high increase in salary and TADA of teaching and non teaching staff.

Table 2

\section{Common Size Comparative Income Statement}




\begin{tabular}{|c|c|c|c|c|c|c|c|c|c|c|}
\hline \multirow[t]{2}{*}{ Particulars } & \multicolumn{2}{|l|}{$069 / 70$} & \multicolumn{2}{|l|}{$070 / 71$} & \multicolumn{2}{|l|}{$071 / 72$} & \multicolumn{2}{|l|}{$072 / 73$} & \multicolumn{2}{|l|}{$073 / 74$} \\
\hline & Rs. & $\%$ & Rs. & $\%$ & Rs. & $\%$ & Rs. & $\%$ & Rs. & $\%$ \\
\hline $\begin{array}{l}\text { Total revenue } \\
\text { Administrative and } \\
\text { operating expenses }\end{array}$ & 87646332 & 100 & 76900639 & 100 & 61543303 & 100 & 89440064 & 100 & 121302680 & 100 \\
\hline Salary and TADA & 49175133 & 56.1 & 58238205 & 75.73 & 56929500 & 92.50 & 60708903 & 67.9 & 75974740 & 62.63 \\
\hline $\begin{array}{l}\text { Electricity, water } \\
\text { and communication }\end{array}$ & 514634 & 0.6 & 517623 & 0.7 & 424906 & 0.7 & 588381 & 0.7 & 811112 & 0.7 \\
\hline Office operating exp. & 2440039 & 2.8 & 8200760 & 10.7 & 4248709 & 6.9 & 4810653 & 5.4 & 3291365 & 2.7 \\
\hline Deprecation & 4221414 & 4.8 & 5222060 & 6.8 & 4998850 & 8.1 & 4718094 & 5.3 & 6935710 & 5.7 \\
\hline $\begin{array}{l}\text { Taxes, charges and } \\
\text { donation }\end{array}$ & 690918 & 0.8 & 651265 & 0.9 & 720987 & 12 & 417323 & 0.5 & 320844 & 0.3 \\
\hline $\begin{array}{l}\text { Registration and } \\
\text { exam fee }\end{array}$ & 4203993 & 4.8 & 4311288 & 5.6 & 4813293 & 7.8 & 5042574 & 5.6 & 5026492 & 4.2 \\
\hline $\begin{array}{l}\text { Student welfare and } \\
\text { scholarship }\end{array}$ & 2597799 & 2.9 & 1180010 & 1.5 & 1918190 & 3.1 & 2535190 & 2.8 & 3082976 & 2.5 \\
\hline $\begin{array}{l}\text { Advertising, sports, } \\
\text { lab materials and } \\
\text { general meeting }\end{array}$ & 924448 & 1.1 & 434064 & 0.6 & 600772 & 0.9 & 687556 & 0.7 & 794503 & 0.7 \\
\hline $\begin{array}{l}\text { BBA program } \\
\text { expenses }\end{array}$ & 425944 & 0.5 & 884191 & 1.3 & 404996 & 0.7 & 2969120 & 3.3 & 2717151 & 2.2 \\
\hline $\begin{array}{l}\text { UGC program } \\
\text { expenses }\end{array}$ & 600387 & 0.7 & 105557 & 0.14 & 251785 & 0.4 & 369260 & 0.4 & 329356 & 0.3 \\
\hline Total expenses & 65794709 & 75.1 & 79745023 & $\begin{array}{l}103.7 \\
0\end{array}$ & 75311988 & 122.4 & 82847054 & 92.6 & 99284249 & 81.9 \\
\hline Surplus (Deficit) & 21851623 & 24.9 & (2844386) & (3.7) & (13768685) & (22.37) & 6593010 & 7.37 & 22018431 & 18.2 \\
\hline
\end{tabular}

Source: Annual reports of JMC (069/70 - 073/74)

Horizontal trend percent analysis shows the analysis of financial statement over a series of years. The percentage is useful for comparing financial statements of different years as they depict changes and trends of several headings. The analysis is made after taking the year 069/70 as the base year. The horizontal trend percent analysis of asset and liabilities show changes in performance and highlight the trend (table 3). Long term fund, outstanding expenses and advance given are in increasing trend. But reserve and surplus declined to $95 \%$ and $65 \%$ in the fiscal year 070/71 and 071/72 and started to increase thereafter. Fixed assets also decreased in the fiscal year $071 / 72$ and $072 / 77$ and then there was remarkable change from $98 \%$ to $149 \%$ based on $069 / 70$. Hence, all assets and liabilities (except campus development fund and outstanding expenses) were in raising trend from the fiscal year 071/72.

Table 3

Horizontal Trend Percent Analysis of Assets and Liabilities: As a \% of 069/70 Level 
Source: Annual reports of JMC (069/70 - 073/74)

\begin{tabular}{|c|c|c|c|c|c|c|c|c|c|c|}
\hline \multirow[t]{2}{*}{ Particulars } & \multicolumn{2}{|c|}{$2069 / 70$} & \multicolumn{2}{|c|}{$2070 / 71$} & \multicolumn{2}{|c|}{$2071 / 72$} & \multicolumn{2}{|c|}{$2072 / 73$} & \multicolumn{2}{|c|}{$2073 / 74$} \\
\hline & Rs. & $\%$ & Rs. & $\%$ & Rs & $\%$ & Rs. & $\%$ & Rs. & $\%$ \\
\hline Capital and & & & & & & & & & & \\
\hline liabilities: & & & & & & & & & & \\
\hline $\begin{array}{l}\text { Reserve and } \\
\text { surplus }\end{array}$ & 53738368 & 100 & 50893982 & 95 & 37125297 & 69 & 43718307 & 81 & 65736738 & 122 \\
\hline $\begin{array}{l}\text { Long term } \\
\text { fund }\end{array}$ & & & & & & & & & & \\
\hline Campus & 12623282 & 100 & 19731272 & 156 & 20871817 & 165 & 25474030 & 202 & 27398432 & 217 \\
\hline fund & $13,43,991$ & 100 & 1343991 & 1 & $13,43,991$ & 1 & $13,43,991$ & 1 & 1343991 & 1 \\
\hline $\begin{array}{l}\text { Account } \\
\text { payables } \\
\text { Outstanding }\end{array}$ & $2,53,555$ & 100 & 48555 & 19 & $1,16,232$ & 45 & $1,16,232$ & 45 & 116232 & 45 \\
\hline $\begin{array}{l}\text { Outstanding } \\
\text { expenses }\end{array}$ & 14584882 & 100 & 25844296 & 177 & 28420088 & 195 & 36984577 & 254 & 43281001 & 297 \\
\hline Total & 8,2544078 & 100 & 9,7862096 & 119 & 8,7877425 & 106 & 107637137 & 130 & 137876394 & 167 \\
\hline $\begin{array}{l}\text { Assets: } \\
\text { Fixed assets }\end{array}$ & 4,5528884 & 100 & 47929175 & 105 & 45069743 & 99 & 45018244 & 98 & 67930853 & 149 \\
\hline $\begin{array}{l}\text { Fixed } \\
\text { deposit }\end{array}$ & $59,63,982$ & 100 & $1,17,52,982$ & 197 & $1,05,64,786$ & 177 & $1,48,66,007$ & 249 & 14866007 & 249 \\
\hline $\begin{array}{l}\text { Bank } \\
\text { balance }\end{array}$ & 2,3984989 & 100 & 1,7548568 & 73 & 7915820 & 33 & 15720535 & 66 & 18126707 & 76 \\
\hline Advance & $65,26,866$ & 100 & $2,01,24,000$ & 308 & $2,37,24,000$ & 363 & $3,14,49,539$ & 482 & 36474739 & 559 \\
\hline $\begin{array}{l}\text { Losing } \\
\text { stock }\end{array}$ & 539357 & 100 & 507371 & 94 & 603076 & 112 & 582812 & 108 & 477907 & 89 \\
\hline Total & 8,2544078 & 100 & 97862096 & 119 & 87877425 & 106 & 107637137 & 130 & 137876394 & 167 \\
\hline
\end{tabular}

Table 4 shows that the total income declined to 88 percent and 70 percent in the fiscal year $070 / 71$ and 2071/72 respectively. Then the revenue began to increase. Salary and TADA and registration and exam fee expenses are increasing subsequently. Office operating expenses were in rising and falling order. BBA program expenses had high fluctuation during the study period. In aggregate, total expenditures had gradually increased from 100 percent of fiscal year 2069/70 to 154 percent in the fiscal year 2073/74. But it decreased in the year 071/72.

Table 4

Horizontal Trend Percent Analysis of Income Statement as a Percent of 069/70 Level

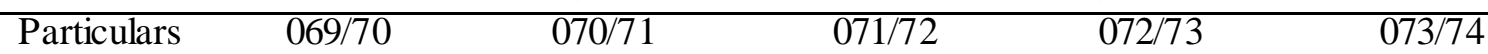




\begin{tabular}{|c|c|c|c|c|c|c|c|c|c|c|}
\hline & Rs. & $\%$ & Rs. & $\%$ & Rs. & $\%$ & Rs. & $\%$ & Rs. & $\%$ \\
\hline Total revenue & $876,46,332$ & 100 & $769,00,639$ & 88 & $615,43,303$ & 70 & $894,40,064$ & 102 & $1213,02,680$ & 138 \\
\hline \multicolumn{11}{|c|}{ Admin is trative and operating expenses } \\
\hline $\begin{array}{l}\text { Salary and } \\
\text { TADA }\end{array}$ & $4,91,75,133$ & 100 & $5,82,38,205$ & 118 & $5,69,29,500$ & 116 & $6,07,08,903$ & 124 & $7,59,74,740$ & 155 \\
\hline \\
\hline $\begin{array}{l}\text { water and } \\
\text { communication }\end{array}$ & $5,14,634$ & 100 & $5,17,623$ & 101 & $4,24,906$ & 83 & $5,88,381$ & 114 & $8,11,112$ & 157 \\
\hline & $24,40,039$ & 100 & $82,00,760$ & 336 & $42,48,709$ & 174 & $48,10,653$ & 197 & $32,91,365$ & 135 \\
\hline Deprecation & $42,21,414$ & 100 & $52,22,060$ & & $49,98,850$ & & $47,18,094$ & & $69,35,710$ & \\
\hline $\begin{array}{l}\text { Taxes, charges } \\
\text { and donation }\end{array}$ & $6,90,918$ & 100 & $6,51,265$ & 94 & $7,20,987$ & 104 & $4,17,323$ & 60 & $3,20,844$ & 46 \\
\hline $\begin{array}{l}\text { Registration and } \\
\text { exam fee }\end{array}$ & $42,03,993$ & 100 & $43,11,288$ & 103 & $48,13,293$ & 114 & $50,42,574$ & 120 & $50,26,492$ & 120 \\
\hline $\begin{array}{l}\text { Student welfare } \\
\text { and scholarship }\end{array}$ & $25,97,799$ & 100 & $11,80,010$ & 45 & $19,18,190$ & 73 & $25,35,190$ & 98 & $30,82,976$ & 119 \\
\hline $\begin{array}{l}\text { Advertising, } \\
\text { sports, lab } \\
\text { materials and }\end{array}$ & & & & & & & & & & \\
\hline general meeting & $9,24,448$ & 100 & $4,34,064$ & 47 & $6,00,772$ & 65 & $6,87,556$ & 74 & $7,94,503$ & 86 \\
\hline $\begin{array}{l}\text { BBA program } \\
\text { expenses }\end{array}$ & $4,25,944$ & 100 & $8,84,191$ & 206 & $4,04,996$ & 95 & $29,69,120$ & 697 & $27,17,151$ & 638 \\
\hline $\begin{array}{l}\text { UGC program } \\
\text { expenses }\end{array}$ & $6,00,387$ & 100 & $1,05,557$ & 18 & $2,51,785$ & 42 & $3,69,260$ & 62 & $3,29,356$ & 55 \\
\hline Total expenses & $6,57,94,709$ & 100 & $7,97,45,023$ & 121 & $7,53,11,988$ & 114 & $8,28,47,054$ & 126 & $9,92,84,249$ & 151 \\
\hline Surplus & $2,18,51,623$ & 100 & $(28,44,386)$ & (13) & $\begin{array}{l}(1,37,68,68 \\
5)\end{array}$ & (63) & $65,93,010$ & 30 & $2,20,18,431$ & 101 \\
\hline
\end{tabular}

Source: Annual reports of JMC (069/70 - 073/74)

Table 5 shows profitability ratios and cost recovery rate of JMC. Return on as sets measures, the relationship between surplus generated and assets used to produce those profits. Return on net worth is an important measurement of an organization. It shows how efficiently the company uses net worth to earn positive total revenue. Net surplus margin is bottom line margin that indicates how well management has been able to convert revenue into earning available for reinvestment. Cost recovery ratio is the ratio of total revenue to total operating expenses and is a main indicator of financial performance. All the ratios were higher in the fiscal year 069/70. Then, these were declined in the following two years. After the fiscal year 071/72, the ratios showed an increasing trend. The mean ratio of return on total assets, return on fixed assets, and return on net worth, net surplus and cost recovery are positive. As the standard deviations are less than 28 , it can be concluded that there is not high dispersion among the figures of study period. In other words, low standard deviation indicates that the ratios are close to the expected value.

Table 5

Profitability Ratios and Cost Recovery Rate

\begin{tabular}{lrrrrrrr}
\hline Particulars & $069 / 70$ & $070 / 71$ & $071 / 72$ & $072 / 73$ & $073 / 74$ & mean & SD \\
\hline Return on total assets & 26.47 & $(2.91)$ & $(15.67)$ & 6.13 & 15.97 & 5.998 & 14.61 \\
Return on fixed assets & 48.00 & $(5.93)$ & $(30.55)$ & 14.65 & 32.41 & 11.716 & 27.75
\end{tabular}


$\begin{array}{llllllll}\text { Return on net worth } & 32.93 & (4.03) & (23.74) & 9.53 & 23.64 & 7.666 & 20.10\end{array}$

$\begin{array}{llllllll}\text { Net surplus ratio } & 24.93 & (3.7) & (22.37) & 7.37 & 18.15 & 4.876 & 16.74\end{array}$

$\begin{array}{lllllllll}\text { Cost recovery rate } & 1.33 & 0.96 & 0.82 & 1.08 & 1.22 & 1.082 & 0.18\end{array}$

Source: Annual reports of JMC (069/70 - 073/74)

The estimated regression equation is $\mathrm{Y}=4,53,27,866+0.403687 \mathrm{X}$ shows that the estimated fixed expenses of the campus is Rs. 4,53,27,866 when the income equal to zero and each additional one rupee of income will cause to increase the expenses by about Rs. 0.40. The correlation between income and expenses is 0.723238 means that there is perfect positive relationship between them. The calculated value of $\mathrm{P}$ is greater than the table value, the $\mathrm{H}_{1}$ is accepted and there is not significant relationship between income and expenses. Coefficient of determination $\left(r^{2}\right)$ is 0.523 which indicates that 52.3 percent of variation in expenses is explained by the income of the campus.

\section{Conclusion}

Financial performance analysis is the analysis of success and failure of any organization which is helpful to make plan and to take decision for future sustainability. The analysis is based on financial statement. The main objective of this paper is to assess financial performance in terms of profitability and cost recovery for a specified time period of five years. Measurement of performance is made on the basis of Horizontal analysis, vertical analysis, cost recovery rate, return on assets, return on fixed assets, return on net worth and net surplus ratio. The study reveals that the financial performance of the campus is good and is in improving stage in the latest years. It has been maintaining good quality financial performance and further can improve if the campus concentrates its managerial skill to minimize cost and maximize total revenue keeping its objectives in mind as far as possible. There is positive relation between income and expenses. It will be fruitful to analyze the income and expenses on the basis of its different cost and revenue centre.

\section{Acknowledge ment}

I would like to take this golden opportunity to express profound gratitude and deep regard to Prof. Dr. Vikash Kumar K.C. for his valuable feedback and regular encouragement throughout the duration of study period. I would also like to give a very special word of thanks to Ravi Bhandari, Sailendra Adhikari, Resam lal poudel and Saksham Bhandari for providing precious help and support without which this research would be incomplete.

\section{References}

Bajkawski, J. (1999). Financial statement analysis: A look at the balance Sheet: Journal of finance, 2(12), 23-45.

Bajracharya, P., Ojha, K.P., Goet, J., Gautam, C.M., Bhattarai, R. \& Shah, B. (2014). Management Accounting. Kathmandu: Asmita Books Publishers and Distributors Pvt. Ltd. 
Bhunia, A., Mukhuti, S. \& Roy, S. G. (2011). Financial performance analysis : A case study: Current Research Journal of Social Science, 3(3), 269-275.

Dangol, R.M. \& Dangol. J. (2010). Management accounting. Kathmandu: Taleju Prakashan Publisher and Distributor

Gupta, R.L. \& Radhaswamy, M. (1996).Advanced accounting. New Delhi: Prentice Hall of India.

Koirala, Y.R., Joshi, P.R., Shakya, S.R., Goet, J.,Shah,B., Shandari, D.R., \& Neupane, R. P. (2013). Accounting for financial analysis and planning. Kathmandu: Asmita Books Publishers and Dis tributors Pvt. Ltd.

Narayanaswamy, R. (2003). Financial accounting: A managerial perspective. New Delhi: Prentice Hall of India Private Limited.

Pilai, R. S. N. \& Bagavathi (1998). Advanced accountancy. Main Vikash Marg, Delhi: Konark Publishers Pvt. Ltd.

Ravichandran, M. \& Subramanian, V. (2016). A study of financial performance analysis of Force Motors Limited: International Journal for Innovative Research in Science \& Technology, 2(11), 662-666.

Sultan, A.S. (2014). Financial statement analysis, measurement of performance and profitability: Applied study of Baghdad Soft Drink Industry: Research Journal of Finance and Accounting 5(4), 49-56. 